\title{
Geogenesis and pedogenesis of well drained brown soils on the youngest Late Weichselian Meuse terrace in North Limburg, Netherlands
}

\author{
A. G. Jongmans and R. Miedema \\ Agricultural University, Department of Soil Science and Geology, P.O. Box 37, \\ 6700 AA Wageningen, Netherlands
}

Received 2 April 1985; accepted 3 December 1985

Key words: Late Weichselian Meuse terraces, brown soils, sedimentation, soil formation, argillic horizon, Alfisols, Luvisols, Plaggepts

\begin{abstract}
The Meuse terraces of Late Weichselian and Holocene age can be subdivided into 4 levels. The youngest Late Weichselian terrace occurs partly along and close to the present-day Meuse. On recent soil maps the well drained brown soils, occupying the highest positions of this terrace level, have been indicated as Plaggepts. This implies the presence of a plaggen epipedon of more than $50 \mathrm{~cm}$ thick.

This study concludes that the brown top-soils are due to periodic Holocene sedimentation followed by homogenization. The sandy loam and finer-textured Late Weichselian subsoils have a clear argillic horizon. These soils should be classified as Alfisols (Luvisols) rather than Plaggepts.
\end{abstract}

\section{Introduction}

On the soil map 1:50.000 sheet 52 East-Venlo (Stiboka, 1975) as well as on the 1:10.000 soil map of Melderslo (Stiboka, 1977) large areas of the well drained brown soils along the present-day Meuse are indicated as Plaggepts ('Bruine Enkeerdgronden'; de Bakker \& Schelling, 1966) with a plaggen epipedon of more than $50 \mathrm{~cm}$ thick (Fig. 1A). In the description of the mapping units some possible modes of formation of the brown top-soils are given. Application of organic manure with some mineral material, customary in the farming system before 1900 (Pape, 1970; van de Westeringh, 1973) could be responsible for the raising of the surface and the formation of the plaggen epipedon. This mode of formation is advocated by $\mathbf{K} . \mathbf{J}$. Hoeksema (personal communication). Also deep tillage is a possible cause.

Van den Broek (1966) indicated these soils in the description of the mapping units (78 and 79) of the 1:200.000 soil map of Limburg as 'well drained brown river terrace soils with argillic-B horizons or spodic horizons depending on texture'. This 
suggests minor human influence on the soil formation. The presence of the assumed clay illuviation (argillic-B horizon) in the finer-textured variants was later confirmed micromorphologically (Miedema et al., 1983). The German soil map 1:50.000 sheet L4502-Geldern (Geologisches Landesamt, 1975), surveyed in cooperation with the 1:50.000 sheet 52 East (Stiboka, 1975), indicates these soils as 'Braune Auenböden und Auenbraunerden' with risk of flooding. No human influence is mentioned. A study by Druijff (1979) on similar soils of the Late Weichselian Rhine system near Ottersum casted doubt on the anthropogenic nature of the top-soil. The landscape development and the terrace levels (Fig. 1A) have been analysed by Miedema et al. (1983), and compared with the interpretation of van den Broek \& Maarleveld (1963). Based mainly on reconstructed topographical elevation, terrace levels are distinguished which correspond closely with those of van den Broek \& Maarleveld (1963). Terrace level I, the highest, is assumed to be of Pre-Bølling age. Terrace level IV occurs at the lowest elevation and dates from the Holocene. Terrace level III is assumed to be of Late Dryas/Preboreal age. The distinction between terrace levels III and IV is difficult because of overlapping elevations.

Recent observations during periods of flooding of the Meuse, and data and maps from the State Water Authority (Limburg) concerning water heights and frequency of flooding have been studied and interpreted together with the soil data.

\section{Methods}

Three characteristic soil profiles in the Lomm region on terrace level III (Fig. 1B) were studied macromorphologically and micromorphologically and samples were analysed for the particle size distribution and selected chemical properties (Table 1).

Horizon nomenclature is according to FAO (1977); the structure description is partly according to Jongerius (1957) and the classification is according to de Bakker \& Schelling (1966), FAO (1974) and USDA (1975). The micromorphological terminology is mainly according to Brewer (1964). Particle size analyses are done at the Soil Testing Laboratory in Oosterbeek with standard techniques (Anon., 1976). Organic carbon was determined potentiometrically according to Begheijn (1976), and total $\mathrm{P}_{2} \mathrm{O}_{5}$ content was determined in a $\mathrm{HF}$ extract (Begheijn, 1980).

\section{Profile descriptions (abridged)}

\section{Soil 1}

\section{General data}

- coordinates N 384.300-E208.850; topographic map 1:50.000, sheet 52 East

- elevation $16.3 \mathrm{~m}$ + NAP (Amsterdam Ordnance Datum)

- flat plateau position

- well drained with imperfectly drained subsoil 

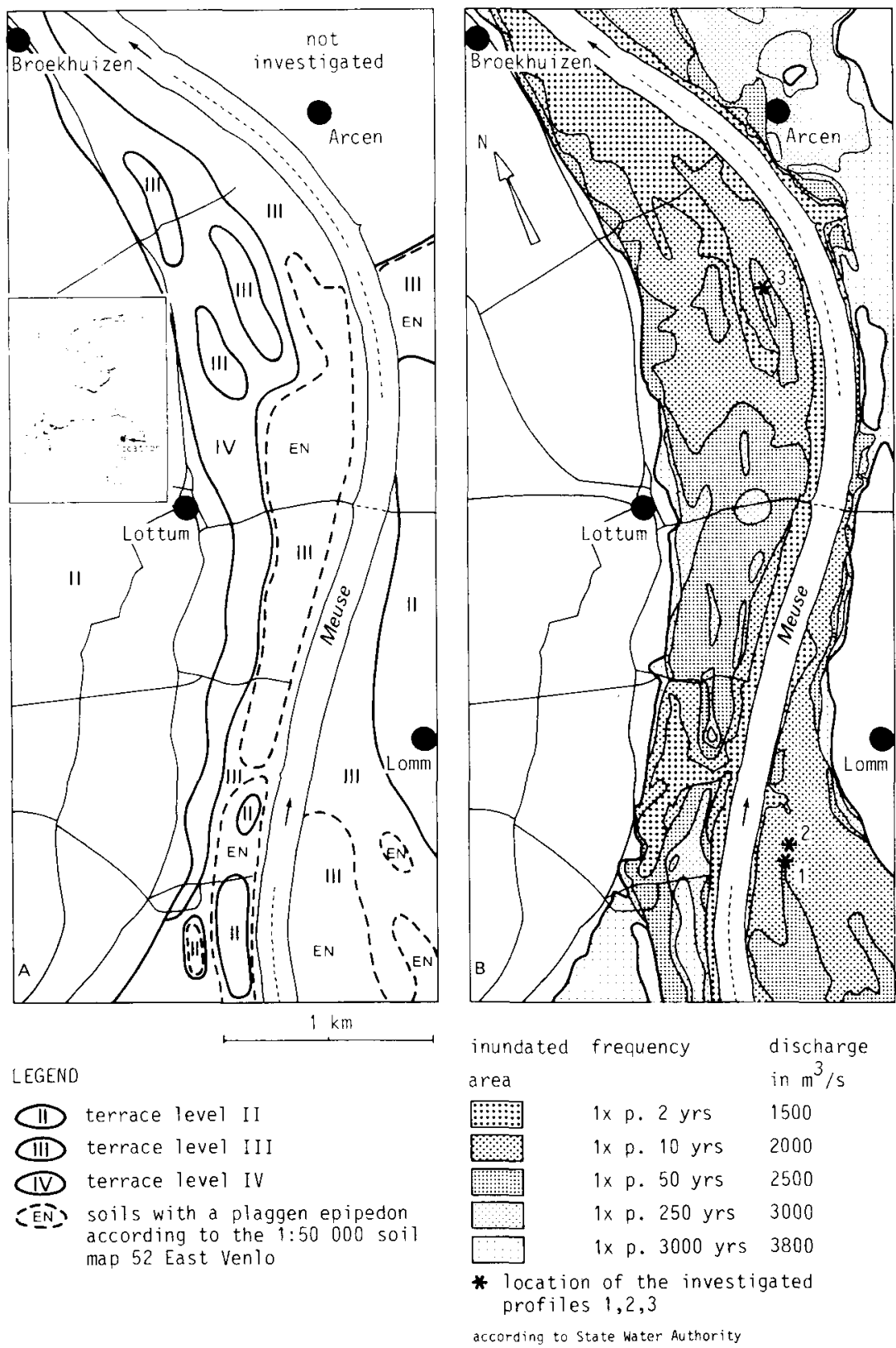

Fig. 1A and B. (A) Relation between river discharge, inundated area and frequency of inundation in the Lomm region. (B) Location of terrace III according to Miedema et al. (1983) and location of Plaggept soils according to Stiboka (1975). 


\section{A. G. JONGMANS AND R. MIEDEMA}

Table 1. Physical, chemical and micromorphological data of soils 1,2 and 3.

\begin{tabular}{|c|c|c|c|c|c|c|c|c|c|}
\hline \multirow[t]{2}{*}{ Horizon } & \multirow[t]{2}{*}{$\begin{array}{l}\text { Depth } \\
(\mathrm{cm})\end{array}$} & \multicolumn{3}{|c|}{$\begin{array}{l}\text { Particle size }(\% \mathrm{w} / \mathrm{w}) \\
\text { distribution }\end{array}$} & \multirow{2}{*}{$\begin{array}{l}\text { Org. } \\
\text { C } \\
(\%)\end{array}$} & \multirow[t]{2}{*}{$\begin{array}{l}\mathrm{pH}- \\
\mathrm{KCl}\end{array}$} & \multirow[t]{2}{*}{$\begin{array}{l}\mathrm{CaCO}_{3} \\
(\%)\end{array}$} & \multirow[t]{2}{*}{$\begin{array}{l}\mathrm{P}_{2} \mathrm{O}_{5} \\
(\%)\end{array}$} & \multirow{2}{*}{$\begin{array}{l}\text { Ferriargilans } \\
\text { + papules } \\
\text { (\% vol) }\end{array}$} \\
\hline & & $<2 \mu \mathrm{m}$ & $2-50 \mu \mathrm{m}$ & $>50 \mu \mathrm{m}$ & & & & & \\
\hline \multicolumn{10}{|l|}{ Soil 1} \\
\hline Ap & $0-27$ & 6.7 & 14.7 & 78.6 & 0.89 & 6.4 & 0.1 & 0.15 & 0.0 \\
\hline $\mathrm{Ah}$ & $27-43$ & 8.3 & 19.4 & 72.3 & 0.56 & 4.1 & 0.0 & 0.13 & 0.0 \\
\hline $2 \mathrm{Bt} 1+2 \mathrm{Bt} 2$ & $43-78$ & 12.5 & 20.2 & 67.3 & 0.54 & 4.0 & 0.0 & 0.13 & \\
\hline $2 B \operatorname{tg} 1$ & $78-107$ & 22.4 & 36.1 & 41.5 & 0.66 & 4.0 & 0.0 & 0.18 & 1.4 \\
\hline $2 B \operatorname{tg} 2$ & $107-114 / 130$ & 25.5 & 23.9 & 50.6 & 0.46 & 5.4 & 0.0 & 0.10 & $\overline{6.5}$ \\
\hline $3 \mathrm{Btg} 3$ & $114 / 130-150$ & 6.3 & 4.2 & 89.5 & 0.20 & 5.5 & 0.0 & 0.10 & \\
\hline $3 B \operatorname{tg} 3$ & $150-160$ & 3.3 & 9.6 & 87.1 & 0.07 & 6.2 & 0.0 & 0.02 & 6.2 \\
\hline \multicolumn{10}{|l|}{ Soil 2} \\
\hline Ap & $0-27$ & 4.9 & 13.3 & 81.8 & 1.27 & 5.6 & 0.1 & 0.19 & 0.0 \\
\hline Ah1 & $27-40$ & 5.0 & 15.5 & 79.5 & 0.77 & 5.0 & 0.0 & 0.13 & 0.0 \\
\hline Ah2 & $40-50$ & 5.2 & 16.2 & 78.6 & 0.70 & 4.4 & 0.0 & 0.10 & \\
\hline $2 \mathrm{~EB}$ & $50-60$ & 6.5 & 17.0 & 76.5 & 0.66 & 4.3 & 0.0 & 0.13 & 0.4 \\
\hline $2 \mathrm{Bt1}$ & $60-70$ & 8.6 & 18.6 & 72.8 & 0.70 & 4.0 & 0.0 & 0.10 & \\
\hline $2 \mathrm{Bt} 1$ & $70-80$ & 14.2 & 21.2 & 64.6 & 0.68 & 4.1 & 0.0 & 0.13 & \\
\hline 2Bt1 & $80-90$ & 14.3 & 19.6 & 66.1 & 0.59 & 4.5 & 0.0 & 0.15 & 1.6 \\
\hline 2Bt1 & $90-100$ & 18.5 & 18.7 & 62.8 & 0.53 & 4.8 & 0.0 & 0.14 & \\
\hline $2 \mathrm{Bt} 1$ & $100-110$ & 16.6 & 14.9 & 68.5 & 0.45 & 5.0 & 0.0 & 0.13 & \\
\hline $2 \mathrm{Bt} 2$ & $110-120$ & 16.4 & 9.7 & 73.9 & 0.32 & 5.1 & 0.0 & 0.30 & $\overline{4.5}$ \\
\hline $3 \mathrm{~B}+3$ & $120-150$ & 0.8 & 2.3 & 96.9 & 0.09 & 5.6 & 0.1 & 0.04 & \\
\hline $3 \mathrm{Bt} 3$ & $120-150$ & 7.3 & 1.7 & 91.0 & 0.18 & 6.2 & 0.0 & 0.06 & 6.0 \\
\hline \multicolumn{10}{|l|}{ Soil 3} \\
\hline Ap & $0-20$ & 7.4 & 15.7 & 76.9 & 1.52 & 4.7 & 0.1 & 0.14 & 0.0 \\
\hline $\mathrm{Ah}$ & $20-65$ & 9.9 & 23.0 & 67.1 & 0.52 & 4.6 & 0.0 & 0.10 & 0.4 \\
\hline $2 \mathrm{Bt} 1$ & $65-90$ & 18.5 & 37.1 & 44.4 & 0.42 & 4.9 & 0.0 & 0.12 & 1.0 \\
\hline $2 \mathrm{Bt} 2$ & $90-130$ & 22.6 & 30.5 & 46.9 & 0.61 & 4.8 & 0.0 & 0.12 & 2.2 \\
\hline
\end{tabular}

\section{Horizon description}

Ap $\quad(0-27 \mathrm{~cm}): \quad$ very dark grayish brown loamy coarse sand (10 YR 3/2); macrostructureless; few spots containing clean coarse sand grains; abrupt and smooth on

Ah $\quad(27-43 \mathrm{~cm}): \quad$ brown loamy coarse sand $(7.5 \mathrm{YR} 5 / 4)$; sponge structure; some channels infilled with clean coarse sand grains; gradual and smooth on

2Bt1 (43-59 cm): brown to reddish brown loamy coarse sand (7.5 YR to 5 YR 4/4); sponge structure; some channels filled in with clean coarse sand grains; gradual and smooth on

2Bt2 (59-78 cm): reddish brown sandy loam (5 YR 4/4); sponge structure; some channels infilled with clean coarse sand grains; abrupt and wavy on 
2Btg1 $(78-107 \mathrm{~cm}): \quad$ very pale brown and strong brown clay loam $(10 \mathrm{YR} 7 / 3+$ 7.5 YR 5/6); weak rough prismatic structure subdivided into strong fine (sub)angular blocky structure; FeMn concretions notably in the pale-brown part; abrupt and wavy on

2Btg2 (107-114/ $130 \mathrm{~cm})$ :

$3 \mathrm{Btg} 3(114 / 130-$ $160 \mathrm{~cm})$ : mottled yellowish red to reddish yellow clay loam (5 YR 5/8$6 / 8$ with common very pale brown (10 YR 7/3) mottles; weak very coarse rough prismatic subdivided into strong (sub)angular blocky structure; abrupt and wavy on laminated yellowish red loamy coarse sand (5 YR 5/8); macrostructureless and brownish yellow coarse sand (10 YR 6/6) single grain; very pale brown mottles (10 YR 7/3) in both layers.

Soil 2

\section{General data}

- coordinates N384.100-E208.790, topographic map 1:50.000, sheet 52 East

- elevation $16.3 \mathrm{~m}+$ NAP (Amsterdam Ordnance Datum)

- flat plateau position

- well drained

\section{Horizon description}

Ap (0-27 cm): dark brown loamy coarse sand (10 YR 3/3); macrostructureless; abrupt and smooth on

Ah $(27-40 \mathrm{~cm}): \quad$ dark yellowish brown loamy coarse sand (10 YR 4/4); sponge structure; some channels partly infilled with clean coarse sand grains; gradual and smooth on

2 EB (40-57 cm): brown to dark brown loamy coarse sand (7.5 YR 4/4); sponge structure; some channels partly filled with clean coarse sand grains; clear and smooth on

$2 \mathrm{Bt} 1 \quad(57-109 \mathrm{~cm}): \quad$ reddish brown sandy loam (5 YR 4/4); sponge structure within weak coarse rough prismatic subdivided into weak fine subangular blocky; some channels partly filled with clean coarse sand grains; gradual and smooth on

$2 \mathrm{Bt} 2(109-120 \mathrm{~cm})$ : yellowish red loamy coarse sand (5 YR 4/6); macrostructureless; clear and smooth on

$3 \mathrm{Bt} 3(120-150 \mathrm{~cm})$ : laminated brown to dark brown loamy coarse sand $(7.5 \mathrm{YR}$ 4/4) macrostructureless and yellow coarse sand (10 YR 7/6); single grain.

Soil 3

\section{General data}

- coordinates N386.875-E209.725, topographic map 1:50.000, sheet 52 East

- elevation $16.0 \mathrm{~m}$ + NAP (Amsterdam Ordnance Datum) 
- flat plateau position

- well drained

Horizon description

Ap (0-20 cm): dark brown loamy coarse sand (10 YR 3/3); macrostructureless; clear and smooth on

Ah (20-65 cm): dark yellowish brown loamy coarse sand (10 YR 4/4); macrostructureless with depth sponge structure; some channels filled with clean coarse sand (very pale brown, 10 YR 7/4); gradual and smooth on

2Bt1 (65-90 cm): brown to dark brown sandy loam (7.5 YR 4/4); sponge structure to weak subangular blocky structure; some channels filled with clean coarse sand; diffuse and smooth on

2Bt2 (90-130 cm): brown to dark brown sandy loam $(7.5$ YR 4/4); sponge structure to weak subangular blocky structure.

\section{Micromorphological characteristics}

\section{Soil 1}

From $0-43 \mathrm{~cm}$ more glauconite skeleton grains are observed than in underlying horizons. Some $\mathrm{CaCO}_{3}$ skeleton grains are found from $0-27 \mathrm{~cm}$. The plasma is composed of clay, iron and organic matter and the basic fabric of the groundmass is agglomeroplasmic. From $43-114 / 130 \mathrm{~cm}$ the basic fabric of the groundmass changes with depth from agglomeroplasmic to porphyroskelic. From $43-59 \mathrm{~cm}$ granotubules occur with a diameter of $2-5 \mathrm{~mm}$. Ferriargillans and derived papules are present, from 43 to $114 / 130 \mathrm{~cm}$ mainly in a clustered distribution pattern. (The proportion is indicated in Table 1.) Below $114 / 130 \mathrm{~cm}$ free grain ferriargillans in a banded distribution pattern occur, part of which are pale yellow. Ferrimanganiferous nodules occur and partly cover ferriargillans and derived papules below $78 \mathrm{~cm}$.

\section{Soil 2}

Some $\mathrm{CaCO}_{3}$ skeleton grains have been observed between $0-17 \mathrm{~cm}$. The basic fabric of the groundmass from $0-57 \mathrm{~cm}$ is agglomeroplasmic and the plasma is composed of clay, iron and organic matter. Regularly granotubules with diameters between 2 and $7 \mathrm{~mm}$ have been observed till $120 \mathrm{~cm}$. From $57-120 \mathrm{~cm}$ the basic fabric of the groundmass is agglomeroplasmic partly intertextic. The plasma is composed of clay and iron and plasma is more abundant than above. Ferriargillans and derived papules are quantified in Table 1 . From $40-70 \mathrm{~cm}$, mainly papules are observed in a clustered and from $120-150 \mathrm{~cm}$ free grain ferriargillans are found in a banded distribution pattern.

\section{Soil 3}

From $0-20 \mathrm{~cm}$ some $\mathrm{CaCO}_{3}$ skeleton grains are observed. The basic fabric of the groundmass from $0-65 \mathrm{~cm}$ is agglomeroplasmic. The plasma is composed of clay, iron and organic matter. Regularly granotubules are found with diameters $2-7 \mathrm{~mm}$. 
From $65-130 \mathrm{~cm}$ the basic fabric of the groundmass changes from agglomeroplasmic to porphyroskelic. The plasma consists of clay and iron. Ferriargillans and derived papules are quantified in Table 1. From 55 to $65 \mathrm{~cm}$ papules are observed in a clustered distribution pattern.

\section{Physical and chemical characteristics}

Table 1 presents the simplified particle size frequency distribution and some chemical data from the described profiles. The detailed particle size analyses available from top-soils and subsoils of the reported profiles and other investigated profiles indicate similar distributions, with varying amounts of coarse and fine fraction.

Fig. 2 shows that soils on terrace levels III and IV have a coarser sand fraction than those on terrace levels II and I.

The top-soils contain 5-10\% clay. The distribution within the $<50 \mu \mathrm{m}$ fraction is similar to that of the underlying, unquestionably fluvial, subsoil deposits. The finer textured fluvial subsoil deposits (12-25\% clay) in turn overly fluvial coarse sandy deposits with 1-6\% clay.

The organic $\mathrm{C}$ content of the Ap horizons ranges from 0.9 to $1.5 \%$. Below the Ap horizons the values in the Ah horizons range between 0.5 and $0.8 \%$. In the

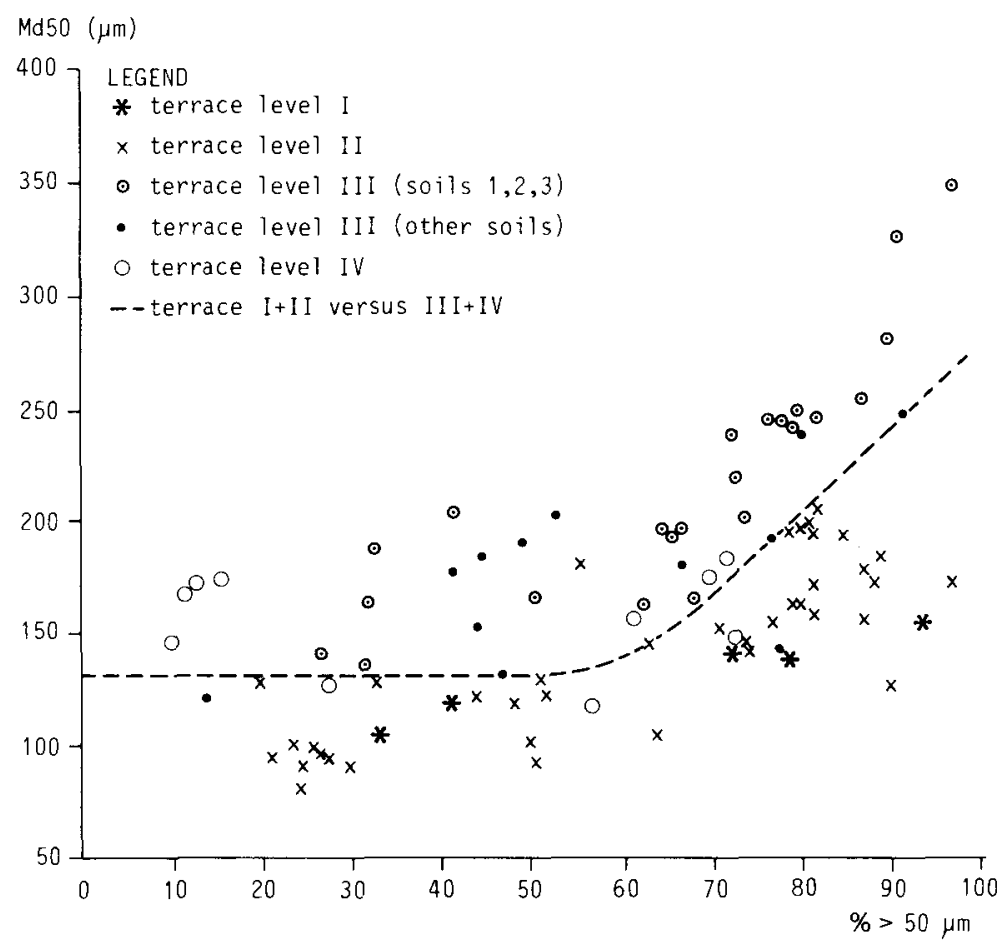

Fig. 2. Sand content and median of the relative sand fraction in relation to terrace levels. 
fine-textured $2 \mathrm{Bt}$ horizons the organic $\mathrm{C}$ values range between 0.4 and 0.7 . The organic $\mathrm{C}$ values of the $\mathrm{Ah}$ and $2 \mathrm{Bt}$ horizons do not show a significant difference.

The total $\mathrm{P}_{2} \mathrm{O}_{5}$ content of the Ap horizons ranges between 0.14 and $0.19 \%$. Below the Ap horizons the values in the Ah horizons range between 0.10 and $0.13 \%$. In the fine-textured $2 \mathrm{Bt}$ horizons the values range between 0.10 and $0.18 \%$. The total $\mathrm{P}_{2} \mathrm{O}_{5}$ contents of the $\mathrm{Ah}$ and $2 \mathrm{Bt}$ horizons do not show a significant difference.

\section{Frequency and effects of flooding}

Fig. 1B shows the flooded area and the flooding frequency in relation to the various discharges of the river for part of the investigated area. For the same area the occurrence of Plaggepts according to Stiboka (1975) on terrace level III (Miedema et al., 1983) is indicated in Fig. 1A. Terrace level III including the area where Plaggepts are indicated is almost completely inundated once every 50 years and large parts of level III are inundated once every 10 years. State Water Authority (Limburg) data indicate that sites of profiles 1, 2 and 3 were inundated in 1926, 1980 and 1984. In the spring of 1984 we observed that brown coarse sand (10 YR 7/4) was deposited in layers $1 \mathrm{~mm}$ to $10 \mathrm{~cm}$ thick (Fig. 3) on the highest parts of terrace level III, where the described profiles are situated. Thin black clayey layers of about 1 $\mathrm{mm}$ thick were deposited in microdepressions and on top of the sand layer (Fig. 4). Aged farmers reported that this phenomenon occurred a number of times during their lifetime and they used to redistribute the sand by spade and wheelbarrow.

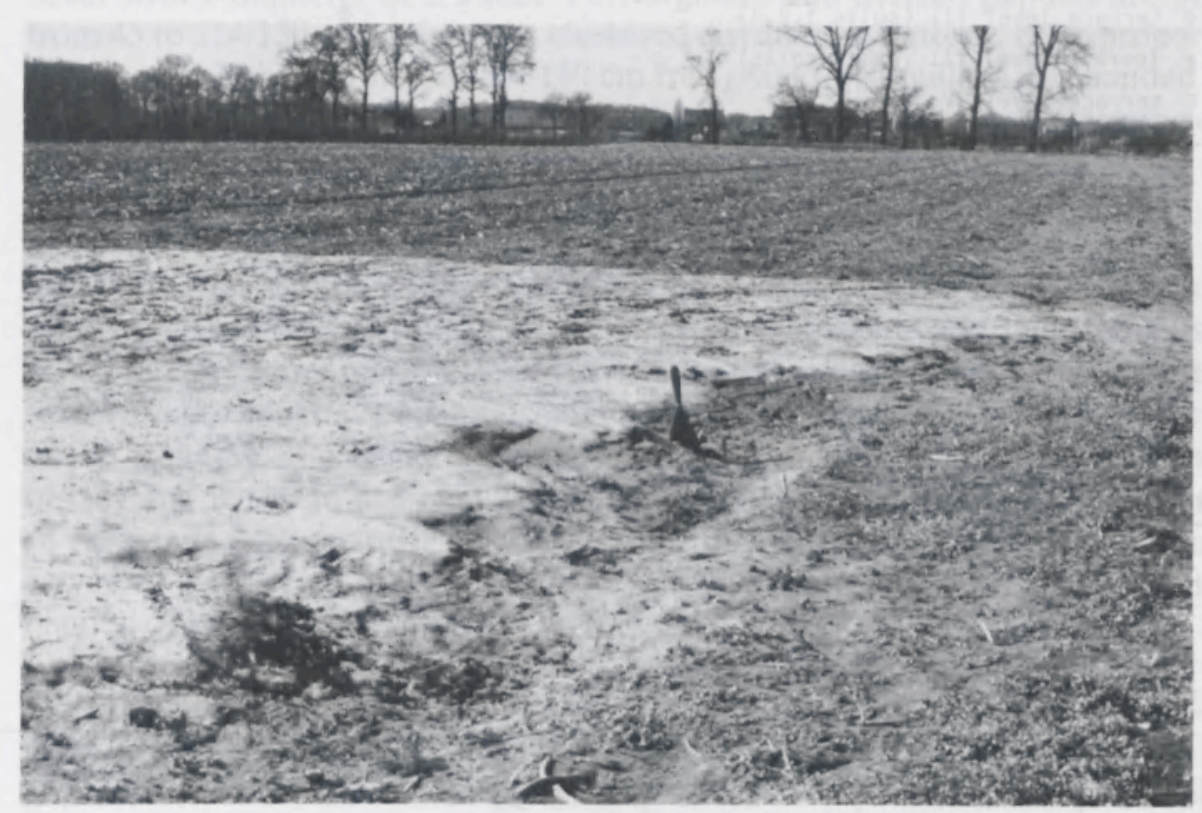

Fig. 3. Deposition of coarse sand (light part) on terrace level III in 1984. 


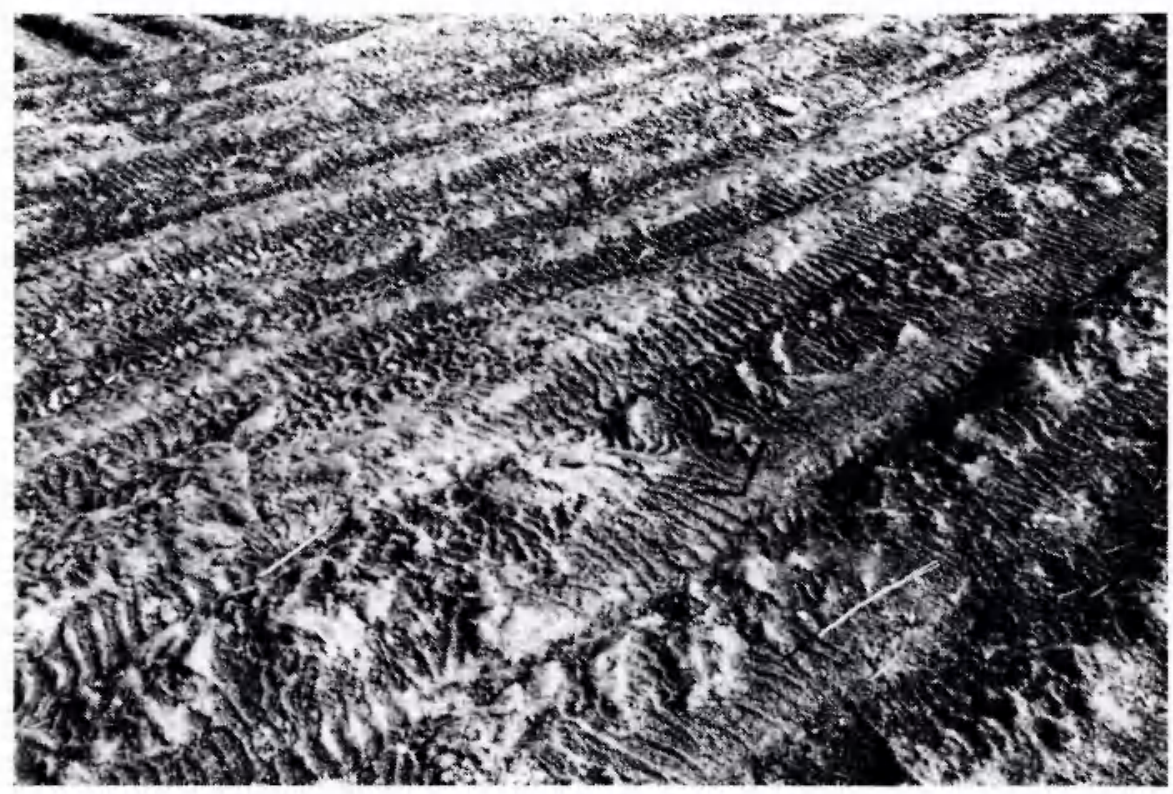

Fig. 4. Sedimentation of a thin discontinuous clay layer (dark part) on top of the deposited coarse sand layer (light part) on terrace level III in 1984.

\section{Interpretation and discussion}

The micromorphological observations clearly indicate the presence of an argillic-B horizon (FAO, 1974) in the reported profiles. The minimum depth at which clay illuviation features are encountered is between 40 and $60 \mathrm{~cm}$. Maximum amounts of clay illuviation are found between 90 and $110 \mathrm{~cm}$ depth (Table 1). The former E horizon is completely masked by later biological homogenization. This is indicated by the dominance of papules in clustered distribution pattern in the top part of the illuvial horizon. With depth a more random distribution pattern and an increasing amount of undisturbed ferriargillans are found.

This argillic- $B$ is invariably found in finer-textured deposits of all Late Weichselian terrace levels (Miedema et al., 1983) and was also encountered in presently imperfectly and poorly drained Late Weichselian Rhine and Meuse sediments (Miedema et al., 1978). The argillic horizon is believed to be of Late Weichselian to Early Preboreal age (Hoeksema \& Edelman, 1960; Miedema et al., 1983). Similarly, Langohr \& Pajares (1983) and van Vliet \& Langohr (1983) concluded a Late Weichselian formation of the argillic-B horizon and its degradation phenomena in Weichselian loess and other silty soils in Belgium and Northern France. Schröder (1979) found an argillic-B horizon in Late Weichselian to Preboreal well-drained soils along the Lower Rhine in West Germany. In contrast, clay illuviation phenomena are absent in Holocene Rhine and Meuse sediments (van den Broek \& Maarleveld, 1963; de Bakker, 1965; R. Miedema, in preparation).

Grain-size frequency analyses indicate that in our profiles a sandy top-soil of 40 
to $60 \mathrm{~cm}$ thickness is present. The clay content in these top-soils ranges between 5 and $10 \%$. Detailed grain-size frequency analyses indicate a similarity between distributions in the silt and sand fractions of top-soils and subsoils. This suggests that both top-soils and subsoils are of fluvial origin but that the top-soils, by absence of clay illuviation phenomena, are of Holocene age. This implies that on terrace level III, the Late Weichselian surface was $40-60 \mathrm{~cm}$ lower than the present surface.

The map of Fig. 1B indicates that terrace level III is frequently inundated. Each inundation is accompanied by sedimentation and this sedimentation could easily account for the sandier top-soils of 40-60 cm thickness if the 10000 years of possible Holocene sedimentation are taken into account. The quoted frequency of flooding relates to the present-day surface level. Due to lower surface level and to more irregular discharges of the River Meuse before canalization, flooding has been more frequent in the past.

The coarse sand and the clayey films of the Holocene floods are mixed together and with the finer-textured Pleistocene subsoil. This accounts for the gradual boundary between Holocene top-soil and Pleistocene subsoil and for the gradual increase in silt and clay content with depth. In all profiles, the presence of granotubules points to biological homogenization. The latter is also responsible for the absence of stratification.

Also the arable use of the soil and the well-drained conditions have promoted biological activity, homogenization and brunification. Old topographic maps (among others those of Tranchot, 1803-1813) indicate arable use for the higher parts of terrace level III, but this use presumably predates these maps by several centuries.

An anthropogenic origin of the sandy top-soil is very unlikely. Trenching below the 'plaggen epipedon' as mentioned by Pape (1970) for the cover sand area, was never encountered at the boundary of sandy top-soils and clayey Late Weichselian subsoils of the terraces. Nor does the grain-size distribution of the sandy top-soil correspond with that of local river dunes and cover sand. It is very unlikely that the sand deposited during the Holocene floodings has been used in the stables. As a source of material it was too unpredictable and small if compared with the large area of terrace III that was covered by a 'plaggen epipedon' in the soil map. Chemical analyses as well contradict the presence of a man-made top-soil. There is no abrupt change in carbon contents at the transition to the finer subsoil, nor such a change in phosphate content. Pape (1970) indicated that all plaggen epipedons have $\mathrm{P}_{2} \mathrm{O}_{5}$ contents of more than $0.1 \%$. This value is exceeded in all our analyses (Table 1), but again there is no abrupt transition between sandy top-soil and clayey subsoil. We therefore conclude that the 40 to $60 \mathrm{~cm}$ thick sandy top-soils on terrace level III are of sedimentary origin and are due to periodic flooding during the Holocene. The coarse material is sedimented during high water, while the finer clay deposits represent the quiet, receding water and is mainly found in depressions. Tillage (Fig. 5), levelling and biological homogenization lead to the characteristic topsoils. Pedogenesis and geogenesis alternated and mutually influenced the top-soils.

The soils are consequently Luvisols (FAO, 1974) or Alfisols (USDA, 1975) and not Plaggepts. The sandy top-soils could be indicated on maps as a phase, as was al- 


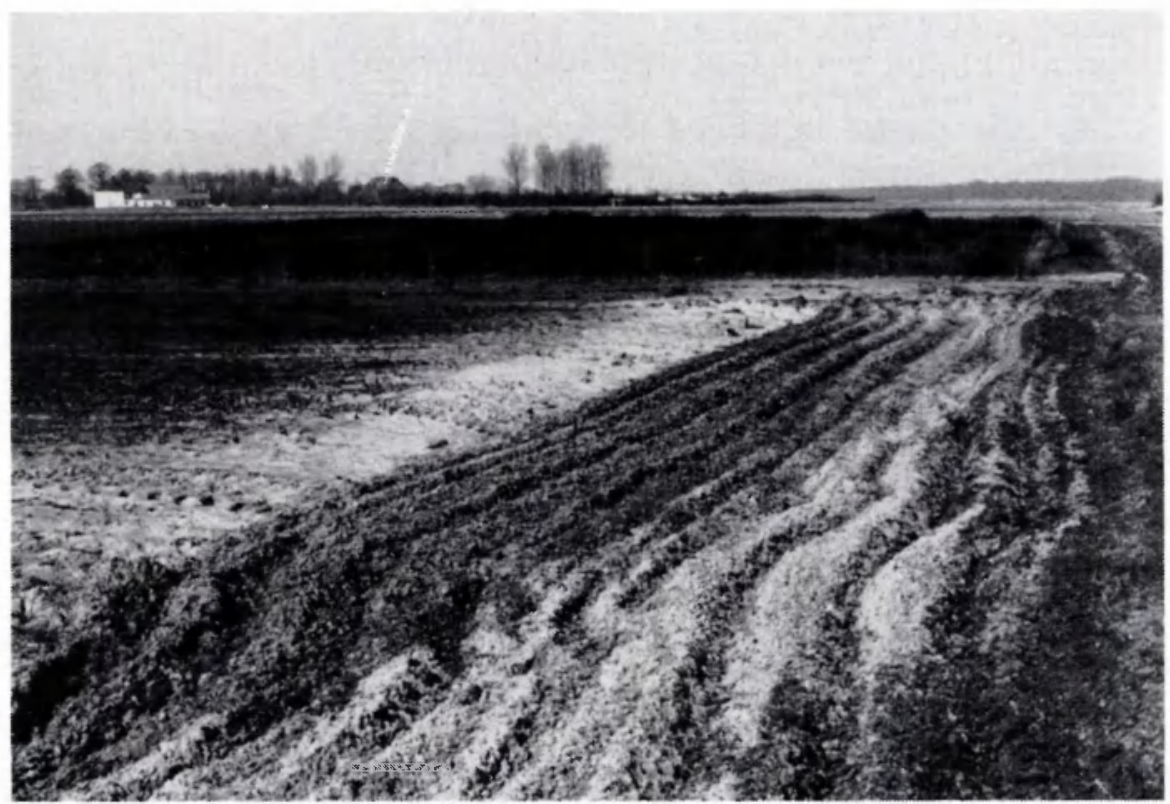

Fig. 5. Tillage incorporates the sedimentated sand layer on terrace level III in the tilled top-soil.

ready done on the soil map of the Roermond area (58E; Stiboka, 1968). On this map, the soils were indicated as BZ: Luvisols with a sandy top-soil. The described mechanism of periodic flooding, sedimentation and homogenization may have been operative on each of the four terrace levels. Extensive areas with a supposed plaggen epipedon have also been indicated on terrace levels I and II (Stiboka, 1975, 1977). The fringes of terrace level II are still periodically flooded; one record is known from this century (1926; van Hees, 1984).

Human influence has been reported from terrace level I, where a darker coloured horizon may separate sandy top-soil and clayey subsoil (Stiboka, 1975). Potsherds were found in such a layer (de Haan et al., 1983). We intend to report on soils of level II and I in a subsequent publication.

\section{Acknowledgements}

The authors wish to thank the State Water Authority, Limburg for permission to use the flooding frequency map and measured water heights. We wish to express our appreciation for the detailed comments on this manuscript by Dr P. Buurman.

\section{References}

Anonymous, 1976. Voorlopig overzicht analyse methodieken. Intern Rapport, Bedrijfslaboratorium voor Grond-en Gewasonderzoek, Oosterbeek, $19 \mathrm{pp}$.

Bakker, H. de, 1965. Tonverlagerung in Flussablagerungen verschiedener Art. Mitteilungen der Deut- 
schen Bodenkundlichen Gesellschaft 4: 123-128.

Bakker, H. de \& J. Schelling, 1966. Systeem van bodemclassificatie voor Nederland. De hogere niveaus. Pudoc, Wageningen, $217 \mathrm{pp}$.

Begheijn, L. Th., 1976. Determination of organic and inorganic carbon in soils by potentiometry. Analyst 101: 710-716.

Begheijn, L. Th., 1980. Methods of chemical analyses for soils and water. Internal report, Dept. Soil Science and Geology, Agricultural University, Wageningen, $100 \mathrm{pp}$.

Brewer, R., 1964. Fabric and mineral analysis of soils. Wiley, New York, $470 \mathrm{pp}$.

Broek, J. M. M. van den, 1966. De bodem van Limburg. Toelichting bij blad 9 van de Bodemkaart van Nederland 1:200.000. Pudoc, Wageningen, $147 \mathrm{pp}$.

Broek, J. M. M. van den \& C. G. Maarleveld, 1963. The Late-Pleistocene terrace deposits of the Meuse. Mededelingen van de Geologische Stichting, Nieuwe serie No 16: 13-25.

Druijff, 1979. Een onderzoek naar de aanwezigheid van bruine oud bouwlanddekken nabij Heumen, Veldhunten, Ottersum en Ven-Zelderheide. Unpublished M.Sc. thesis, Agricultural University, Wageningen, $41 \mathrm{pp}$.

FAO, 1977. Guidelines for soil description, FAO, Rome, 66 p.

FAO-Unesco, 1974. Soil map of the World 1:5.000.000, Volume 1: Legend Paris, $59 \mathrm{pp}$.

Geologisches Landesamt, 1975. Bodenkarte von Nordrhein-Westfalen 1:50.000 Blatt 14502 Geldern.

Haan, F. de, C. Kasse \& E. Zilverberg, 1983. Geogenese van het Looiveld. De geogenese van het microrelief op het oudste Laat Glaciale Maasterras in de omgeving van Swolgen (Noord Limburg). Unpublished M.Sc. thesis, Agricultural University, Wageningen, $58 \mathrm{pp}$.

Hees, J. van, 1984. Broekhuizen toen. Werkvoorzieningschap N.L.W. Venray, 104 pp.

Hoeksema, K. J. \& C. H. Edelman, 1960. The role of biological homogenisation in the formation and transformation of gray-brown podzolic soils. Transactions 7th International Congress of Soil Science (Madison), Vol. 4: 402-405.

Jongerius, A., 1957. Morfologische onderzoekingen over de bodemstructuur. Bodemkundige studies No 2. Mededelingen Stiboka, Wageningen, 93 pp.

Langohr, R. \& G. Pajares, 1983. The chronosequence of pedogenic processes in fraglossudalfs of the Belgium loess belt. In: P. Bullock \& C. P. Murphy (Eds.), Soil micromorphology, Vol. 2. Soil genesis, p. 503-511. A.B. Academic Publishers, Berlihamsted, U.K.

Miedema, R., E. van Engelen \& Th. Pape, 1978. Micromorphology of a toposequence of Late Pleistocene fluviatile soils in the Eastern part of the Netherlands. In: M. Delgado (Ed.), Micromorfologia de Suelos, Vol. 1, p. 469-501. T. Arte Prieto Moreno, Maracena (Granada), Spain.

Miedema, R., S. Slager, A. G. Jongmans \& Th. Pape, 1983. Amount, characteristics and significance of clay illuviation features in Late-Weichselian Meuse deposits. In: P. Bullock \& C. P. Murphy (Eds.), Soil micromorphology, Vol. 2. Soil genesis: p. 519-529. A.B. Academic Publishers, Berkhamsted, U.K.

Pape, J. C., 1970. Plaggen soils in the Netherlands. Geoderma 4(3): 229-257.

Schröder, D., 1979. Bodenentwicklung in Spätpleistozänen und Holozänen Hochflutlehmen des Niederrheines. Habilitationschrift, Bonn, 296 pp.

Stiboka, 1968. Bodemkaart van Nederland 1:50.000. Toelichting bij kaartblad 58 Oost-Roermond. Pudoc, Wageningen, $113 \mathrm{pp}$

Stiboka, 1975. Bodemkaart van Nederland 1:50.000. Toelichting bij kaartblad 52 Oost-Venlo. Pudoc, Wageningen, $197 \mathrm{pp}$.

Stiboka, 1977. Ruilverkaveling Melderslo. Vol. 1. Bodemgesteldheid, geomorfologie en landschap. Vol. II: Aanhangsels. Rapport No 1273, Stiboka, Wageningen, 272 pp.

USDA, 1975. Soil taxonomy. A basic system of soil classification for making and interpreting soil surveys. USDA Agricultural Handbook 436. Soil Survey Staff, Washington, 754 pp.

Vliet, B. \& R. Langohr, 1983. Evidence of disturbance by frost of pore ferri-argillans in silty soils of Belgium and Northern France. In: P. Bullock and C. P. Murphy (Eds.), Soil micromorphology, Vol. 2: Soil genesis, p. 511-518. A.B. Academic Publishers, Berkhamsted, U.K.

Westeringh, W. van de, 1973. Bodemkundig onderzoek aan oudbouwlandgronden in Noord-Limburg. Landbouwkundig Tijdschrift 85: 195-200. 